\title{
PERAN PERSEPSI DUKUNGAN ORGANISASI TERHADAP KESIAPAN MENGHADAPI PERUBAHAN DENGAN MODAL PSIKOLOGIS SEBAGAI MEDIATOR
}

\author{
Cecilia Giwan Meilian ${ }^{1}$, Rita Markus Idulfilastri ${ }^{2}$, Fransisca I. R. Dewi ${ }^{3}$ \\ ${ }^{1}$ Program Studi Magister Psikologi, Universitas Tarumanagara Jakarta \\ Email: cecilia.707199103@stu.untar.ac.id \\ ${ }^{2}$ Fakultas Psikologi, Universitas Tarumanagara Jakarta \\ Email: ritamarkus@fpsi.untar.ac.id \\ ${ }^{3}$ Fakultas Psikologi, Universitas Tarumanagara Jakarta \\ Email: fransiscar@fpsi.untar.ac.id
}

Masuk: 22-04-2020, revisi: 09-10-2020, diterima untuk diterbitkan : 29-10-2020

\begin{abstract}
Change is a necessity because no one can reject or avoid change. This can also happen in organizations, so it is important to be able to see a person's readiness in dealing with changes with the variables that influence it. The main objective of this study was to examine the role of psychological capital as a mediators in the relationship between perceived organizational support and readiness of change in PT X. Participants were 150 employees of PT $X$, a subsidiary of one of the BUMN. Data were collected using a change readiness questionnaire based on the Holt scale, Armenakis (2007), the scale of the perception of organizational support by Eisenberger, Huntington, Hutchinson, \& Sowa (1986) to measure perceived organizational support. Psychological capital is measured using a concept from Luthans, Youssef-Morgan, Avolio (2015) which was later developed by the Faculty of Psychology at Tarumanagara University. Data processing using linear regression has proven the perceived of organizational support directly has a positive and significant effect on readiness of changes in PT X. The contribution of the variable perception of organizational support in explaining the variable readiness of change is $30.2 \%$. Perceived organizational support have a positive and significant effect on readiness to face change through psychological capital mediators at PT X. The contribution of readiness of change and psychological capital in explaining the variables of readiness to face change is $46.6 \%$.
\end{abstract}

Keywords: psychological capital, perceived organizational support, readiness of change

\begin{abstract}
ABSTRAK
Perubahan adalah keniscayaan karena tidak ada seorang pun yang dapat menolak atau menghindar dari perubahan. Hal ini pun dapat terjadi di organisasi, sehingga penting untuk dapat melihat kesiapan seseorang dalam menghadapi perubahan dengan mempertimbangkan variabel-variabel yang mempengaruhinya. Tujuan utama dari penelitian ini adalah untuk menguji peran mediator modal psikologis terhadap hubungan persepsi dukungan organisasi dengan kesiapan menghadapi perubahan di PT X. Partisipan adalah 150 karyawan PT X, anak usaha salah satu BUMN. Data dikumpulkan menggunakan kuesioner kesiapan berubah berdasarkan skala Holt, Armenakis (2007), skala studi persepsi dukungan organisasi oleh Eisenberger, Huntington, Hutchinson, \& Sowa (1986) untuk mengukur persepsi dukungan organisasi. Variabel modal psikologis diukur dengan menggunakan konsep dari Luthans, YoussefMorgan, Avolio (2015) yang kemudian dikembangkan oleh Fakultas Psikologi Universitas Tarumanagara. Pengolahan data menggunakan regresi linear telah membuktikan persepsi dukungan organisasi secara langsung berpengaruh positif dan signifikan terhadap kesiapan menghadapi perubahan di PT X. Kontribusi dari variabel persepsi dukungan organisasi dalam menjelaskan variabel kesiapan menghadapi perubahan sebesar $30.2 \%$. Persepsi dukungan organisasi berpengaruh positif dan signifikan terhadap kesiapan menghadapi perubahan melalui mediator modal psikologis di PT X. Kontribusi dari variabel persepsi dukungan organisasi dan modal psikologis dalam menjelaskan variabel kesiapan menghadapi perubahan sebesar $46.6 \%$.
\end{abstract}

Kata Kunci: modal psikologis, persepsi dukungan organisasi, kesiapan menghadapi perubahan

\section{PENDAHULUAN}

Perusahaan melakukan langkah perubahan untuk mentransformasikan model bisnisnya agar semakin kompetitif. Hal ini dilakukan perusahaan untuk mengikuti tuntutan pasar dan perkembangan teknologi informasi. Kondisi ini pun terjadi di PT X yang merupakan salah satu 
anak perusahaan BUMN yang bergerak di bidang trading energi dan distribusi manajemen logistik. Berbagai perubahan diakui dan dirasakan oleh PT X sejak 2012 yaitu pergantian Direksi yang konsisten sesuai dengan hasil RUPS, kebijakan penggabungan sales induk perusahaan dengan sales anak perusahaan pada tahun 2019, serta penambahan jumlah proyek diluar bisnis rutin yang signifikan meningkat 174\% dari tahun 2018 ke 2019. Perubahan struktur organisasi dan program digitalisasi juga terjadi didalam organisasi PT X pada tahun 2018 sampai dengan 2020 yaitu di fungsi keuangan, sales, dan juga operasional. Hal tersebut dapat disimpulkan bahwa perubahan dapat dikatakan adalah hal yang tidak dapat dipungkiri dan dialami dalam setiap lini di PT X. Kondisi yang terjadi berdampak bagi sumber daya manusia di PT X untuk siap dalam menghadapi perubahan yang terjadi.

Boudreau dan Ramstad (2007) berpendapat bahwa sumber daya manusia merupakan aset organisasi yang sangat vital, salah satu indikator penting dalam pencapaian tujuan organisasi. Sumber daya manusia selaku asset perusahaan diharapkan siap dalam menghadapi perubahan sehingga kesuksesan strategi perusahaan dapat tercapai. Ketidaksiapan anggota organisasi untuk berubah, menjadi hambatan bagi keberhasilan perubahan karena anggota organisasi merupakan orang yang terkena dampak dari perubahan organisasi, yang sangat berperan pada keberhasilan program perubahan yang telah direncanakan (Mangundjaya, 2016). Menurut Armenakis (1993), kesiapan berubah merupakan keyakinan, perilaku, dan intensi seseorang terhadap perubahan yang dibutuhkan dan terkait dengan persepsi mereka terhadap kapasitas individual dan organisasinya untuk mencapai keberhasilan dalam perubahan tersebut. Keberhasilan dalam penerapan perubahan tersebut dapat menjadi keluaran yang diharapkan yaitu kesuksesan implementasi strategi di masa datang (Armenakis, Harris, 1999).

Mangundjaya (2016) berpendapat dalam bukunya bahwa kesiapan dalam menghadapi perubahan dipengaruhi oleh faktor individu dan faktor organisasi. Persepsi karyawan yang belum positif atas kebijakan-kebijakan dan kondisi perusahaan kurang dapat mendukung strategi manajemen dalam menanggapi tantangan yang berlangsung. Rhoades dan Eisenberger (2002) mengungkapkan bahwa persepsi terhadap dukungan organisasi juga dianggap sebagai keyakinan secara umum yang dibentuk oleh karyawan terkait penilaian mereka terhadap kebijakan dan prosedur organisasi. Penelitian Gigliotti (2018) sebelumnya menghasilkan bahwa persepsi dukungan organisasi memiliki hubungan positif dan signifikan dengan kesiapan menghadapi perubahan $(\beta=0.25, \mathrm{p}<0.01)$. Ketika individu merasa yakin bahwa organisasi mendukung mereka dan menghargai kontribusi mereka, dengan kebijakan dan prosedur organisasi yang tepat maka karyawan akan merasa lebih siap menghadapi perubahan yang ada.

Selain dari faktor organisasi terdapat faktor individu yang dapat mempengaruhi kesiapan seseorang dalam menghadapi perubahan. Menurut Kirrane (2016) dari hasil penelitiannya bahwa persepsi karyawan terhadap organisasi yang merupakan hal personal dari masing-masing individu dan juga yang memungkinkan memberi peran besar pada kesiapan individu untuk berubah adalah modal psikologis seseorang. Menurut Avey (2008) modal psikologis merupakan variabel yang sangat berharga di setiap waktu dan setiap kondisi, tapi bahwa situasi yang khususnya mengalami perubahan, modal psikologis menjadi hal yang kritikal. Luthans, Youssef, dan Avolio (2007) mendefinisikan modal psikologis sebagai keadaan psikologi positif individu yang ditandai dengan adanya efikasi diri, optimisme, harapan dan ketahanan untuk mencapai kesuksesan. Individu yang memiliki modal psikologis yang tinggi akan mampu secara fleksibel berperilaku memenuhi tuntutan pekerjaan yang dinamis, sehingga pada saat yang bersamaan akan membantunya dalam meningkatkan kompetensi dan kesejahteraan yang lebih tinggi (Luthans, Youssef, \& Avolio, 2007). Erdem, Deniz dan Camoglu (2015) juga membuktikan 
bahwa persepsi dukungan organisasi memiliki dampak signifikan dan positif terhadap modal psikologis $(\mathrm{p}=0.000<\alpha=0.05)$. Judge (1997) mengatakan bahwa sumber daya personal dapat berfungsi sebagai moderator atau mediator dalam hubungan antara faktor lingkungan dan organisasi, atau bahkan dapat menentukan cara orang memahami lingkungan, merumuskannya dan bereaksi terhadapnya. Penelitian Kirrane (2016) telah meneliti adanya hubungan antara persepsi dukungan atasan terhadap kesiapan menghadapi perubahan dengan modal psikologis sebagai mediatornya $(\beta=0.68, \mathrm{p}<0.001)$ dan memiliki hubungan yang signifikan.

Peneliti melihat masih penting dan diperlukannya penelitian ini dilakukan karena sedikit penelitian yang menjadikan modal psikologis sebagai mediator antara persepsi dukungan organisasi dan kesiapan menghadapi perubahan, khususnya dengan karakteristik anak perusahaan BUMN sehingga dapat memperkaya penelitian Kiranne sebelumnya tentang kesiapan menghadapi perubahan. Selain itu penelitian Kirrane mempertimbangkan variabel persepsi karyawan atas dukungan atasan saja, tidak melingkupi persepsi dukungan secara organisasi, yang saat ini lebih sesuai dalam situasi yang terjadi menyeluruh dalam organisasi PT X. Oleh sebab itu semakin menguatkan peneliti untuk meneliti peran modal psikologis sebagai mediator persepsi dukungan organisasi terhadap kesiapan menghadapi perubahan.

Berdasarkan uraian di atas, maka ditentukan rumusan masalah dalam penelitian ini adalah ingin menguji apakah terdapat hubungan positif antara persepsi dukungan organisasi terhadap kesiapan menghadapi perubahan di PT X dan juga pengujian peran modal psikologis sebagai mediator pada hubungan persepsi dukungan organisasi terhadap kesiapan menghadapi perubahan di PT X. Dengan demikian, model penelitian dapat dilihat pada ilustrasi gambar 1 berikut.

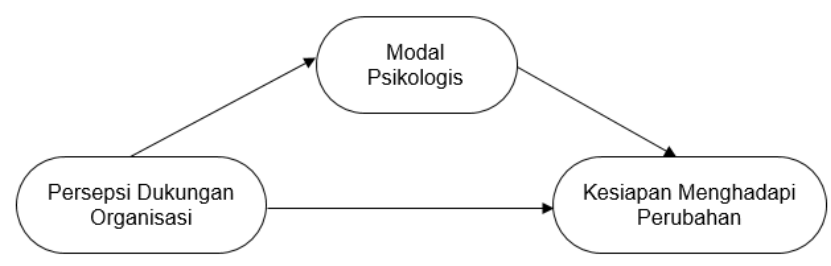

Gambar 1. Hubungan Persepsi Dukungan Organisasi terhadap Kesiapan Menghadapi Perubahan dengan Modal Psikologis sebagai Mediator

\section{METODE PENELITIAN}

\section{Partisipan dan Prosedur Penelitian}

Populasi penelitian ini adalah karyawan PT X di seluruh Indonesia yang memiliki kantor pusat di Jakarta dan 5 kantor region yang tersebar di Indonesia dengan sebutan region Sumatera, region DKI Jabar Banten, region Jateng DIY Jatim Nalinustra, region Kalimantan, dan region Indotim. Karakteristik partisipan yaitu karyawan PT X yang telah memiliki masa kerja lebih dari 2 tahun karena sudah melewati masa penilaian kinerja dan sudah mengalami pergantian kepemimpinan Direksi. Pekerja tersebut berstatus Pekerja Waktu Tidak Tertentu (PWTT) dan bekerja di wilayah kerja PT X, bukan perbantuan dari Induk Perusahaan atau diperbantukan ke anak Perusahaan PT X. Pengambilan sampel menggunakan teknik purposive sampling dikarenakan tidak semua individu dalam populasi memiliki karakteristik yang sesuai dengan tipe penelitian yang akan dilakukan. Jumlah sampel menggunakan perhitungan sampel dari Slovin sebagaimana yang dikutip oleh Riduwan dan Kuncoro (2014) yaitu sebanyak 150 orang. 
Data yang digunakan pada penelitian ini diperoleh melalui penyebaran kuesioner dibulan November 2019 pada karyawan PT X. Pengambilan data dilakukan dengan menggunakan kuesioner yang berbentuk hardcopy dan online survey. Kuesioner online disebarkan melalui whatsapp dimedia elektronik yang dapat diakses langsung oleh responden. Analisis data dilakukan dengan uji korelasi dapat dilakukan dengan Pearson Correlation Product Moment (Sugiyono, 2017). Uji korelasi digunakan untuk mengetahui tingkat hubungan antara persepsi dukungan organisasi dan modal psikologis dengan kesiapan menghadapi perubahan. Dalam penelitian ini digunakan model Pearson Correlation Product Moment dengan bantuan program SPSS versi 23.

\section{Pengukuran}

Alat pengumpulan data yang digunakan adalah kuesioner yang terdiri dari tiga jenis alat ukur. Dalam satu kuesioner tersebut terdiri dari alat ukur kesiapan menghadapi perubahan, persepsi dukungan organisasi, dan modal psikologis. Alat ukur kesiapan menghadapi perubahan milik Holt dan Armenakis (2007) memiliki 4 dimensi Appropriateness, Management Support, Change Efficacy, dan Personal Beneficial dengan rentang skala 1-4 dari sangat tidak setuju - sangat setuju. Variabel kesiapan menghadapi perubahan memiliki dua puluh sembilan butir pernyataan yang terdiri dari dua puluh satu butir positif dan delapan butir negatif. Contoh butir positif dari variabel kesiapan untuk berubah adalah: "Jika perusahaan mengadopsi perubahan maka perubahan ini berguna bagi saya." Sementara contoh butir negatif adalah: "Waktu yang dihabiskan untuk perubahan seharusnya digunakan untuk kepentingan lain." Melalui hasil uji reliabilitas, diketahui bahwa alat ukur kesiapan menghadapi perubahan tergolong reliabel $(\alpha=0.939)$. Hal ini juga diuji untuk alat ukur persepsi dukungan organisasi milik Eisenberger, Huntington, Hutchinson, dan Sowa (1986) dengan skala 1-5 dari sangat tidak setuju sampai dengan sangat setuju, dan dapat dikatakan alat ukur persepsi dukungan organisasi ini tergolong reliabel $(\alpha=0.924)$. Alat ukur ini terdiri dari 36 butir pernyataan, dengan contoh butir pernyataannya adalah: "Perusahaan lebih mementingkan keuntungan (profit) daripada saya."

Alat ukur modal psikologis Luthans, Youssef-Morgan, Avolio (2015) yang kemudian dikembangkan oleh Fakultas Psikologi Universitas Tarumanagara dengan dengan skala 1-6 dari sangat tidak sesuai sampai dengan sangat sesuai. Alat ukur modal psikologis dipergunakan untuk mengukur 4 dimensi, yaitu self-efficacy, hope, optimism, dan resilience. Kuesioner terdiri dari 24 butir, dengan 6 butir pernyataan positif pada masing-masing dimensi. Contoh butir pernyataannya adalah: "Saya merasa percaya diri seandainya harus mewakili bagian atau unit kerja saya dalam rapat dengan manajemen." Melalui hasil uji reliabilitas, diketahui bahwa alat ukur modal psikologis tergolong reliabel $(\alpha=0.903)$.

\section{HASIL DAN PEMBAHASAN}

Berdasarkan uji normalitas dengan metode kolmogorov-smirnov, variabel menunjukkan nilai signifikansi yang lebih besar dari 0.05 , artinya dapat disimpulkan bahwa data terdistribusi normal. Setelah melakukan uji asumsi klasik bahwa data terdistribusi normal, tidak terjadi multikolinieritas, dinyatakan ada hubungan linear antar variabel, dan tidak terjadi heteroskedastisitas maka kemudian peneliti menguji analisis regresi linear antara persepsi dukungan organisasi dengan kesiapan menghadapi perubahan, dapat dilihat pada Tabel 1. 
Tabel 1. Hasil Uji Analisis Regresi Linear

\begin{tabular}{llccc}
\hline Variabel Independen & Variabel Dependen & Beta & $\begin{array}{c}\text { Koefisien } \\
\text { Determinasi }\left(\mathrm{R}^{2}\right)\end{array}$ & Sig. \\
\hline Persepsi Dukungan Organisasi & $\begin{array}{l}\text { Kesiapan Menghadapi } \\
\text { Perubahan }\end{array}$ & 0.550 & 0.302 & 0.000 \\
\hline
\end{tabular}

Kontribusi dari variabel persepsi dukungan organisasi dalam menjelaskan variabel kesiapan menghadapi perubahan sebesar 30.2\% sedangkan sisanya yaitu $69.8 \%$ diprediksi oleh variabel lain dan kemudian nilai regresi kedua variabel tersebut adalah $\mathrm{F}=64.086$ dengan taraf signifikansi $p=0.001(<0.05)$, maka dapat dikatakan bahwa persepsi dukungan organisasi berhubungan signifikan dengan kesiapan menghadapi perubahan.

Peneliti kemudian menguji modal psikologis sebagai mediator antara persepsi dukungan organisasi dengan kesiapan menghadapi perubahan, yang dapat dilihat dalam tabel berikut:

Tabel 2. Hasil Uji Analisis Regresi Linear

\begin{tabular}{llccc}
\hline Variabel Independen & Variabel Dependen & Beta & $\begin{array}{c}\text { Koefisien } \\
\text { Determinasi } \\
\left(\mathrm{R}^{2}\right)\end{array}$ & Sig. \\
\hline $\begin{array}{l}\text { Persepsi Dukungan } \\
\text { Organisasi }\end{array}$ & Modal Psikologis & 0.379 & 0.144 & 0.000 \\
\hline Modal Psikologis & $\begin{array}{l}\text { Kesiapan } \\
\text { Menghadapi }\end{array}$ & 0.583 & 0.340 & 0.000 \\
& $\begin{array}{l}\text { Perubahan } \\
\text { Kesiapan }\end{array}$ & 0.384 & 0.466 & 0.000 \\
\hline $\begin{array}{l}\text { Persepsi Dukungan } \\
\text { Prganisasi dan Modal }\end{array}$ & $\begin{array}{l}\text { Menghadapi } \\
\text { Perubahan }\end{array}$ & 0.438 & & 0.000 \\
\hline
\end{tabular}

Pengujian menggunakan regresi linear antara persepsi dukungan organisasi dengan modal psikologis memiliki nilai koefisien determinasi sebesar 0.144. Dapat dikatakan bahwa kontribusi dari variabel persepsi dukungan organisasi dalam menjelaskan variabel modal psikologis sebesar $14.4 \%$ sedangkan sisanya yaitu $85.6 \%$ diprediksi oleh variabel lain. Nilai regresi kedua variabel tersebut adalah $\mathrm{F}=24.812$ dengan taraf signifikansi $p=0.001(<0.05)$, maka dapat dikatakan bahwa persepsi dukungan organisasi berhubungan signifikan dengan modal psikologis.

Berikutnya yaitu pengujian menggunakan regresi linear antara modal psikologis dengan kesiapan menghadapi perubahan, nilai koefisien determinasi sebesar 0.340. Dapat dikatakan bahwa kontribusi dari variabel modal psikologis dalam menjelaskan variabel kesiapan menghadapi perubahan sebesar 34\% sedangkan sisanya yaitu 66\% diprediksi oleh variabel lain. Nilai regresi kedua variabel tersebut adalah $\mathrm{F}=76.327$ dengan taraf signifikansi $p=0.001(<0.05)$ sehingga dapat dikatakan bahwa modal psikologis berhubungan signifikan dengan kesiapan menghadapi perubahan.

Sementara itu hasil analisis regresi linear dengan dilakukannya secara bersama-sama antara persepsi dukungan organisasi dan modal psikologis dengan kesiapan menghadapi perubahan yang memperoleh nilai koefisien determinasi sebesar 0.466. Dapat dikatakan bahwa kontribusi dari variabel persepsi dukungan organisasi dan modal psikologis dalam menjelaskan variabel kesiapan menghadapi perubahan sebesar $46.6 \%$ sedangkan sisanya yaitu $53.4 \%$ diprediksi oleh variabel lain. Nilai regresi kedua variabel tersebut adalah $\mathrm{F}=64.240$ dengan taraf signifikansi $p=$ 0.001 ( $<0.05)$ sehingga dapat dikatakan bahwa persepsi dukungan organisasi dan modal psikologis secara simultan berhubungan signifikan dengan kesiapan menghadapi perubahan. 
Peran variabel persepsi dukungan organisasi terhadap kesiapan menghadapi perubahan terlihat dari nilai koefisien regresi $\beta=0.384$ dengan taraf signifikansi $p=0.001(<0.05)$, artinya persepsi dukungan organisasi signifikan terhadap kesiapan menghadapi perubahan. Hasil analisis juga menunjukkan bahwa peran variabel modal psikologis terhadap kesiapan menghadapi perubahan memiliki nilai koefisien regresi $\beta=0.438$ dengan taraf signifikansi $p=0.001(<0.05)$ artinya modal psikologis signifikan terhadap kesiapan menghadapi perubahan.

Hasil analisis menunjukkan bahwa persepsi dukungan organisasi memiliki pengaruh yang signifikan terhadap modal psikologis, selanjutnya modal psikologis memiliki pengaruh yang signifikan terhadap terhadap kesiapan menghadapi perubahan. Untuk itu, modal psikologis dapat dikatakan menjadi mediator yang sempurna ketika persepsi dukungan organisasi tidak memiliki pengaruh yang signifikan terhadap kesiapan menghadapi perubahan, namun kenyataannya hasil penelitian justru menyebutkan ada pengaruh yang signifikan. Dengan demikian, modal psikologis dapat dikatakan sebagai mediator sebagian (partial mediator). Hal ini terjadi karena terlihat pengurangan dampak variabel independen terhadap variabel dependen setelah menambahkan variabel pemediasi. Mediasi penuh dicapai jika dampak tersebut menjadi tidak signifikan sedangkan mediasi sebagian tercapai jika dampak tersebut masih signifikan. Pada penelitian menunjukkan bahwa setelah menambahkan Modal Psikologi, dampak persepsi dukungan organisasi yang dirasakan pada kesiapan untuk menghadapi perubahan berkurang tetapi tetap signifikan (dari $\beta=0.550, p<0.001$ menjadi $\beta=0.438, p<0.001$ ).

Penelitian ini mendukung penelitian sebelumnya yang dilakukan oleh Gigliotti (2018) bahwa persepsi dukungan organisasi memiliki hubungan positif dan signifikan dengan kesiapan menghadapi perubahan. Hasil penelitian ini juga menguatkan penelitian Kirrane (2016) bahwa memang terdapat hubungan yang signifikan antara persepsi dukungan atasan terhadap kesiapan menghadapi perubahan dengan modal psikologis sebagai mediatornya $(\beta=0.68, \mathrm{p}<0.001)$. Meskipun hasil penelitian ini menunjukan bahwa modal psikologis berperan sebagai partial mediator, namun hal ini masih sesuai dengan pernyataan yang dikemukakan Judge (1997) bahwa sumber daya personal dapat berfungsi sebagai moderator atau mediator dalam hubungan antara faktor lingkungan dan organisasi. Hasil hubungan langsung yang lebih besar daripada hubungan tidak langsung pada model penelitian ini, menunjukkan bahwa variabel persepsi dukungan organisasi dapat mempengaruhi kesiapan menghadapi perubahan secara lebih besar dibandingkan pengaruhnya melalui modal psikologis sebagai mediator. Meskipun demikian, persepsi dukungan organisasi dan modal psikologis tetap digunakan secara keseluruhan akan memiliki pengaruh yang lebih besar terhadap kesiapan menghadapi perubahan.

\section{KESIMPULAN DAN SARAN}

Hasil penelitian menunjukkan bahwa persepsi dukungan organisasi memiliki hubungan positif dengan kesiapan menghadapi perubahan. Dengan meningkatnya persepsi dukungan organisasi dalam sebuah perusahaan maka dapat meningkatkan kesiapan karyawan dalam menghadapi perubahan. Selanjutnya persepsi dukungan organisasi dapat mempengaruhi kesiapan menghadapi perubahan melalui peran modal psikologis sebagai mediator, dan diketahui bahwa peran modal psikologis pada model penelitian ini adalah sebagai partial mediator. Modal psikologis secara parsial memediasi hubungan antara persepsi dukungan organisasi dengan kesiapan menghadapi perubahan sehingga menunjukkan bahwa modal psikologis bukan merupakan faktor penentu dalam hubungan antara persepsi dukungan organisasi dengan kesiapan menghadapi perubahan. 
Variabel yang dihubungkan dengan kesiapan menghadapi perubahan memang sudah banyak diteliti, namun penelitian mediasi dari persepsi dukungan organisasi ataupun variabel predikto lain terhadap kesiapan menghadapi perubahan masih tergolong sedikit, sehingga bagi peneliti selanjutnya dapat melihat aspek sumber daya psikologis personal lainnya selain modal psikologis, yang mungkin dapat menjadi full mediator dalam suatu model penelitian. Pada penelitian ini penulis mempertimbangkan fenomena masalah dengan memilih modal psikologis sebagai variabel mediator, namun untuk penelitian selanjutnya dapat dipertimbangkan aspek sumber daya psikologis personal lainnya, salah satunya seperti psychological empowerment tetapi dengan tetap memperhatikan fenomena masalah yang berkaitan.

Keterbatasannya dalam penelitian ini yaitu peneliti menggunakan teknik pengambilan sampel simple secara random sampling yang diterapkan pada anggota populasi yang berstrata. Bagi peneliti selanjutnya diharapkan dapat menggunakan teknik sampling yang lebih sesuai lagi untuk diterapkan pada anggota populasi yang berstrata, misalnya dengan proportionate random sampling sehingga hasil temuan dapat dilakukan kajian komparasi lebih lanjut. Jumlah sampel pada penelitian ini juga tergolong kecil, sehingga untuk penelitian selanjutnya sampel dapat dibuat lebih banyak. Selain itu penelitian selanjutnya dapat dilakukan pada perusahaan dibidang lainnya selain anak perusahaan dari badan usaha negara milik negara, hal ini untuk memperbanyak keanekaragaman kesiapan untuk berubah di beberapa jenis usaha lainnya, sehingga dapat diketahui apakah model ini bisa digeneralisasikan ke bidang usaha lain.

\section{Ucapan Terima Kasih (Acknowledgement)}

Terima kasih kami ucapkan kepada PT X yang memberikan dukungan dalam penyelesaian penelitian ini. Peneliti juga mengucapkan terima kasih dan apresiasi pada seluruh partisipan yang telah bersedia untuk menjadi responden pada penelitian ini dan pihak-pihak utama yang berkontribusi dalam penelitian ini.

\section{REFERENSI}

Armenakis, A. A., Harris, S. G., \& Mossholder, K. W. (1993). Creating readiness for organizational change. Human Relations, 46 (6), 681.

Boudreau, J. W., \& Ramstad, P. M. (2007). Beyond HR: The new science of human capital. Harvard Business School Press.

Eisenberger, R., Huntington, R., Hutchison, S., \& Sowa, D. (1986). Perceived organizational support. Journal of Applied Psychology, 71(3), 500-507.

Gigliotti, R., Vardaman, J., Marshall, D. R., \& Gonzalez, K. (2018). The role of perceived organizational support in individual change readiness. Journal of Change Management, 19(2), 86-100.

Holt, D. T., Armenakis, A. A., Field, H. S., \& Harris, S. G. (2007). Readiness for organizational change: The systematic development of a scale. The Journal of Applied Behavioral Science, 43(2), 232-255.

Judge, T. A., Locke, E. A., \& Durham, C. C. (1997). The dispositional causes of job satisfaction; A core evaluations approach. Research in Organizational Behavior, 19, 151-188.

Kirrane, M., Lennon, M., O'Connor, C., \& Fu, N. (2016). Linking perceived management support with employees' readiness for change: The mediating role of psychological capital. Journal of Change Management, 17(1), 47-66.

Luthans, F., Youssef, C. M., \& Avolio, B. J. (2015). Psychological capital and beyond. Oxford University Press.

Luthans, F., Youssef, C. M., \& Avolio, B. J. (2007). Psychological capital developing the human competitive edge. Oxford University Press. 
Luthans, F., Youssef, C. M., \& Avolio, B. J. (2007). Investing and developing positive organizational behavior, the emergence of psychological capital In Cooper \& D. Nelsons. Positive Organizational Behavior.

Mangundjaya, W. L. (2016). Psikologi dalam perubahan organisasi. Swasthi Adi Cita.

Rhoades, L., \& Eisenberger, R. (2002). Perceived organizational support: A review of literature. Journal of Applied Psychology, 87(4), 698-714.

Riduwan, \& Kuncoro, E. (2014). Cara menggunakan dan memaknai path analysis (Analisis Jalur). Alfabeta.

Sugiyono. (2017). Metode penelitian kuantitatif kualitatif dan R\&D. Alfabeta. 